\title{
PEMASARAN PRODUK USAHA MIKRO, KECIL DAN MENENGAH (UMKM) DALAM KEGIATAN WISATA DI DESA CIPACING KABUPATEN SUMEDANG
}

\author{
Edwin Rizal $^{1}$, Ute Lies Siti Khadijah ${ }^{1,2}$, Rully Khairul Anwar ${ }^{1}$ \\ ${ }^{1}$ Fakultas Ilmu Komunikasi, Universitas Padjadjaran, Jl. Raya Bandung-Sumedang KM. 21 Jatinangor, 456363 \\ ${ }^{2}$ Magister Pariwisata Berkelanjutan Sekolah Pascasarjana Universitas Padjadjaran, \\ Jl. Dipati Ukur no. 35 bandung 40132 \\ E-mail: edwin.rizal@unpad.ac.id ; ute.lies@unpad.ac.id ; rully.khairul@unpad.ac.id
}

\begin{abstract}
ABSTRAK
Salah satu potensi yang dapat memajukan perekonomian masyarakat desa adalah potensi kuliner lokalnya. Untuk meningkatkan kesejahteraan masyarakat desa, pemerintah dan masyarakat harus bekerja bersama-sama sehingga sumber daya baik alam dan manusia dapat diberdayakan dengan tepat. Dalam hal ini, pemuda/i desa yang merupakan usia produktif dan juga bonus demografi dalam desa juga dapat bertindak sebagai partisipator dalam mengembangkan dan meningkatkan potensi-potensi desanya. Saat ini kebanyakan memilih untuk menjadi pegawai swasta dan buruh pabrik, tentunya bisa dimaksimalisasi perannya dalam bidang teknologi yaitu pemasaran melalui sosial media. Sebagaimana kita ketahui bahwa Indonesia sendiri merupakan negara dengan tingkat pengguna sosial media yang cukup tinggi di dunia dan pemuda/i merupakan sumber daya manusia yang masih sangat produktif baik dalam hal belajar dan bekerja. Maka, penulis merancang sebuah program pemberdayaan pemuda/i Desa Cipacing yang masih sangat jarang mengecap pendidikan di tingkat perguruan tinggi untuk meningkatkan taraf hidupnya dan memaksimalkan potensi yang dimiliki desa, melalui pembelajaran tentang literasi media dan pemasaran produk kuliner, cendera mata, berbasis online atau melalui media sosial.
\end{abstract}

Kata kunci; Pemasaran, Kegiatan Wisata,

\section{MARKETING OF MICRO, SMALL AND MEDIUM ENTERPRISES (UMKM) IN TOURISM ACTIVITIES IN CIPACING VILLAGE, SUMEDANG DISTRICT}

\begin{abstract}
One of the potentials that can advance the economy of rural communities is the local culinary potential. To improve the welfare of rural communities, the government and the community must work together so that both natural and human resources can be properly empowered. In this case, village youths who are of productive age and also the demographic bonus in the village can also act as participants in developing and increasing the potential of their village. Currently most of them choose to become private employees and factory workers, of course their role in the technology sector can be maximized, namely marketing through social media. As we know, Indonesia itself is a country with a fairly high level of social media users in the world and youth are very productive human resources both in terms of study and work. So, the authors designed a youth empowerment program in Cipacing Village which still rarely gets education at the tertiary level to improve their standard of living and maximize the potential of the village, through learning about media literacy and marketing culinary products, souvenirs, online or through social media.
\end{abstract}

Key words; marketing, tourism activity

\section{PENDAHULUAN}

Saat ini, di Indonesia masih terdapat banyak desa yang belum mampu memaksimalkan potensinya dengan baik. Potensi desa adalah segenap sumber daya alam dan sumber daya manusia yang dimiliki desa sebagai modal dasar yang perlu dikelola dan dikembangkan bagi kelangsungan dan perkembangan desa. Potensi desa di tiap daerah tidaklah sama, tergantung dari keadaan geografis, jumlah penduduk, luas tanah, dan tingkat kesuburan tanah.

Salah satu potensi desa yang masih kurang maksimal dalam pengelolaan dan pengembangannya adalah dari segi sumber daya manusia, baik laki-laki maupun perempuan, usia muda maupun dewasa. Indonesia yang terkenal dengan negara yang memiliki bermacam-macam suku bangsa dan budaya tentunya erat dengan kesenian. Bidang kesenian seperti seni kerajinan tangan, sangat berpotensi dalam mendatangkan keuntungan bagi desa-desa yang ada di Indonesia. Kerajinan tangan sendiri memiliki pengertian yaitu hasil karya seni yang dibuat dengan menggunakan keterampilan tangan seseorang. Di Indonesia, usaha di bidang seni kerajinan merupakan salah satu yang memiliki banyak variasi. Jika dilihat dari data statistik Kementrian Pariwisata dan Ekonomi Kreatif Indonesia di tahun 2014, permintaan produk-produk kerajinan tangan ke luar negeri mengalami peningkatan dari 15,5 triliun hingga 21,7 triliun. Dengan latar belakang data inilah kita bisa melihat jika usaha dalam bidang seni kerajinan tangan memiliki potensi yang tinggi, namun usaha di bidang ini juga sangat bertumpu pada para pengrajinnya yang harus berkualitas. Jatinangor adalah wilayah pegunungan yang berada di perbatasan Bandung - Sumedang. Jatinangor merupakan sebuah kabupaten di wilayah Sumedang. Jatinangor sendiri adalah sebuah wilayah pertanian sekaligus pendidikan, 
karena sebagian mata pencaharian warga adalah bertani. Namun dengan berdirinya kampus-kampus di daerah ini maka terjadilah alih fungsi lahan. Lahan yang sebelumnya digunakan sebagai lahan pertanian berubah menjadi rumah sewa untuk mahasiswa dan pusat perbelanjaan. Di Jatinangor terdapat 12 desa yaitu Cibeusi, Cikeruh, Cilayung, Cileles, Cinta Mulya, Cipacing, Cisempur, Hegarmanah, Jatimukti, Jatiroke, Mekargalih, Sayang. Salah satu desa yang akan dibahas pada penelitian ini adalah Desa Cipacing yang terletak di Jalan Abdul Hamid, Kecamatan Jatinangor. Desa Cipacing memiliki 18 RW, tetapi yang kami teliti hanyalah 4 RW yaitu RW 01 sampai dengan RW 04. Penduduk Desa Cipacing terdapat kurang lebih 2000 jiwa (usia dewasa) dengan jumlah Kepala Keluarga di RW 01 sebanyak 250 Kepala Keluarga, RW 02 sebanyak 220 Kepala Keluarga, RW 03 sebanyak 215 Kepala Keluarga dan RW 04 sebanyak 223 Kepala Keluarga. Penghasilan warga Desa Cipacing rata-rata didapat dari usaha kerajinan tangan dan senapan angin. Tetapi selain itu, masyarakat setempat juga memiliki pekerjaan pokok lainnya, yaitu sebagai guru, pegawai negeri sipil, pegawai pabrik, dan lain-lain. Dahulu, bekerja sebagai pengrajin kerajinan tangan merupakan pekerjaan pokok warga Desa Cipacing. Namun seiring berjalannya waktu, perkembangan zaman dan tuntutan ekonomi, profesi sebagai pengrajin berubah menjadi pekerjaan sampingan. Warga Desa Cipacing saat ini memproduksi kerajinan tangan hanya ketika ada pesanan saja.

Awal mula yang menyebabkan warga Desa Cipacing menggeluti bidang usaha kerajinan tangan ini ialah saat salah seorang warganya ada yang melancong ke Bali dan bekerja di bidang kerajinan. Melihat potensi besar akan banyaknya peminat barang-barang kerajinan tangan tersebut membuatnya tertarik untuk membuat kerajinan yang sama di kampung halaman (Desa Cipacing). Fenomena inilah yang melatarbelakangi merebaknya usaha kerajinan tangan di Dusun Cipacing.

Lalu, pengalamannya yang cukup lama bekerja di Bali membuat dirinya memiliki banyak relasi, salah satunya adalah wisatawan asal Hawai yang akhirnya sering memesan kerajinan tangan asal Desa Cipacing bisa sampai di ekspor ke luar negeri. Saat ini kerajinan tangan asal Desa Cipacing sudah semakin mendunia. Kerajinan tangan ini sudah didistribusikan hingga ke Spanyol, Jamaika dan Mallorca. Untuk pendistribusian dalam negeri sendiri sudah sampai ke Bali, Jambi, Kalimantan dan Aceh. Sedangkan untuk pendisttibusian senapan sudah sampai ke Surabaya. Adapun beberapa kerajinan tangan yang diproduksi diantaranya adalah karimba, suling, celengan, halilintar, panah, ketapel, tik tok, jimbe dan kecrekan. Inilah yang melatarbelakangi kami dalam memilih topik penelitian ini. Rumusan masalah dari penelitian kami adalah :1). Apa potensi yang ada di Desa Cipacing? 2). Apa potensi yang dapat diberdayakan di Desa Cipacing? 3). Bagaimanakah solusi untuk memberdayakan potensi yang ada di Desa Cipacing? Sehingga didapatkan tujuan penelitian yaitu 1). Untuk mengetahui potensi yang ada di Desa Cipacing 2). Untuk mengetahui potensi yang dapat diberdayakan di Desa Cipacing 3). Untuk mengetahui solusi untuk memberdayakan potensi yang ada di Desa Cipacing.
Dengan adanya produk dari desa Cipacing ini diharapkan akan adanya pendatang untuk berkunjung.Kegiatan Pemasaran melalui media daring ini juga diambil oleh bisnis pariwisata. Hal itu menjadi angin segar bagi pemilik bisnis pariwisata guna menggaet wisatawan dalam mengenalkan produk UMKM lebih banyak dari internet. Mereka berlomba-lomba untuk menampilkan sisi terbaik dari destinasi supaya wisatawan bisa terpengaruh untuk datang ke tujuan.

Era media baru ini juga disambut oleh Kementerian Pariwisata. Mereka semakin gencar dengan program Pasar Digital yakni membangun sebuah destinasi pariwisata lokal seraya membangkitkan ekonomi, pemberdayaan masyarakat, budaya, dan lingkungan. Sentuhan digital disandingkan sebagai upaya promosi pemasaran modal tipis dengan koneksi tak terbatas. Upaya digitalisasi merambah tren wisata anyar untuk meramaikan kembali wisata dengan kearifan lokal tanpa unsur maksimalisasi keuntungan satu pihak. Adanya Pasar Digital menjadi industri baru untuk melahirkan kembali budaya kembali ke desa dan menambah nilai serta pengalaman bagi wisatawan.

Selain meramaikan dunia media sosial akan hadirnya pasar digital, modal promosi dengan harga murah dapat mengembangkan pariwisata yang sencar. Promosi pariwisata akan menjadi lebih mudah dan murah dengan adanya aplikasi dan media sosial. Akhirnya, tujuan wisata semakin banyak dikunjungi lantaran terdapat spot foto dan atraksi menarik yang disampaikan lewat beberapa kanal digital. Baik itu video, tulisan, atau foto. Edukasi soal wisata yang berdampak baik lewat media sosial akan menciptakan budaya baru. Wisatawan akan lebih mudah mencerna cara berwisata dengan baik yang diharapkan oleh pembuat destinasi tersebut.

\section{METODE}

Dari permasalahan yang kami teliti, ada satu teori yang menjadi pendukung dalam penelitian kami yaitu teori Konstruksi Sosial oleh Berger dan Luckman. Teori ini menjelaskan pengetahuan individu mengenai kenyataan (fakta objektif) tentang dunia ditentukan oleh lingkungan sosial di mana pengetahuan itu diperoleh dan disalurkan. Kenyataan dan realitas sosial ini pada dasarnya adalah simbol di mana seseorang mempunyai kemampuan untuk menggunakan dan mengaplikasikan simbol tersebut. Teori ini mengkaji hubungan antara pemikiran manusia dengan konteks sosial di mana suatu ide atau pemikiran itu muncul, berkembang, dan disahkan. Komunikasi dua arah berlangsung dalam tiga proses yaitu eksternalisasi yaitu penyesuaian diri para pelaku pemberdayaan dengan sosio kultural masyarakat atau lembaga yang diteliti. Objektivasi yaitu interaksi sosial pelaku pemberdayaan yang dilembagakan. Internalisasi yaitu identifikasi diri pelaku pemberdayaan dengan masyarakat atau lembaga sosial yang akan diberdayakan. Menurut Mc Ardle, pemberdayaan juga adalah proses pengambilan keputusan, lalu keputusan yang telah diambil tersebut haruslah menjadi suatu konsekuensi yang menjadi tujuan hasil akhir dalam memberdayakan keterampilan suatu masyarakat demi mencapai tujuan yang telah disepakati. (Hikmat, 
2006:3). Pemberdayaan masyarakat adalah sebuah proses menolong ketidakberuntungan dalam sebuah kelompok atau individual untuk bersaing secara lebih efektif dengan melihat keuntungan dengan menolong mereka untuk belajar, belajar menggunakan media, terlibat dalam aksi politik, memahami bagaimana bekerja sesuai sistem, dan lain lain. Di mana dalam pemberdayaan ini meliputi fenomena yang diangkat, pengorganisasian masyarakat, advokasi dan sosialisasi. Selain itu ada juga pembahasan mengenai teknologi internet sebagai upaya untuk membantu program pemberdayaan. Minghetti dan Buhalis (2009) mengatakan Teknologi Informasi dan Komunikasi dapat meningkatkan dampak sosial dan ekonomi. Dari sana banyak banyak warga dan organisasi di negara maju dan berkembang dapat memperoleh manfaat. Begitu pun dengan dampak TIK yang menciptakan banyak inovasi sehingga dunia pariwisata cenderung dinamis dan mulai mengembangkan aspek wisata yang berkelanjutan.

Dalam program atau strategi pemberdayaan yang akan dilakukan, tentunya diperlukan evaluasi untuk melihat apakah strategi pemberdayaan tersebut berhasil atau tidak, mendatangkan perubahan atau tidak. Untuk melaksanakan evaluasi tersebut, perlu dilakukan suatu penelitian dengan metode penelitian evaluatif. Terdapat dua metode penelitian evaluatif yang bersifat bottom up; participatory rural appraisal (PRA) dan rapid rural appraisal (RRA).

Participatory Rural Appraisal (PRA) atau Pemahaman Partisipatif Kondisi Pedesaan (PRA) adalah pendekatan dan metode yang memungkinkan masyarakat secara bersama-sama menganalisis masalah kehidupan dalam rangka merumuskan perencanaan dan kebijakan secara nyata. Metode dan pendekatan ini semakin meluas dan diakui kegunaannya ketika paradigma pembangunan berkelanjutan mulai dipakai sebagai landasan pembangunan di negara-negara sedang berkembang. Dalam paradigma pembangunan berkelanjutan, manusia ditempatkan sebagai inti dalam proses pembangunan. Manusia dalam proses pembangunan tidak hanya sebagai penonton tetapi mereka harus secara aktif ikut serta dalam perencanaa, pelaksanaan, pengawasan dan menikmati hasil pembangunan. Metode dan pendekatan yang tampaknya sesuai dengan tuntutan paradigma itu adalah metode dan pendekatan yang partisipatif.

Rapid Rural Appraisal (RRA) merupakan proses belajar yang intensif untuk memahami kondisi perdesaan, dilakukan berulang-ulang, dan cepat. Untuk itu diperlukan cara kerja yang khas, seperti tim kerja kecil yang bersifat multidisiplin, menggunakan sejumlah metode, cara, dan pemilihan teknik yang khusus, untuk meningkatkan pengertian atau pemahaman terhadap kondisi perdesaan. Cara kerja tersebut tersebut dipusatkan pada pemahaman pada tingkat komunitas lokal yang digabungkan dengan pengetahuan ilmiah. Komunikasi dan kerjasama diantara masyarakat desa dan aparat perencana dan pelaksana pembangunan (development agent) adalah sangat penting, dalam kerangka untuk memahami masalah-masalah di perdesaan. Di samping itu, metoda
RRA juga berguna dalam memonitor kecenderungan perubahan-perubahan di perdesaan untuk mengurangi ketidakpastian yang terjadi di lapangan dan mengusulkan penyelesaian masalah yang memungkinkan.

Dalam program pemberdayaan yang dilaksanakan terkait Pemberdayaan Pemuda/i Desa Cipacing dalam Meningkatkan Usaha Kuliner Berbasis Media Sosial ini, penulis memilih untuk menggunakan metode RRA. Berangkat dari tujuan dari program ini sendiri yaitu untuk meningkatkan potensi usaha kuliner masyarakat desa melalui pemasaran berbasis media sosial, sehingga dibutuhkan tenaga ahli atau memiliki latar belakang akademis tertentu dalam merancang atau merencanakan, membimbing, dan mendidik masyarakat, serta mengevaluasi setiap tahapan dalam program yang akan berlangsung.

Berdasarkan hasil yang telah didapatkan, fokus permasalahan yang kami pilih terletak pada sumber daya manusia terutama sumber daya pemuda usia produktif di RW 01 Desa Cipacing. Sumber daya manusia pemuda RW 01 Desa Cipacing dapat diberdayakan. Solusi yang kami tawarkan terhadap permasalahan kurangnya minat pemuda akan bisnis kerajinan tangan serta kurangnya pengetahuan dan kesadaran pemuda dalam pemanfaatan teknologi internet adalah diadakannya workshop bekelanjutan mengenai bisnis dan pemanfaatan teknologi internet untuk membangkitkan minat dan pengetahuan para pemuda di Desa Cipacing. Dengan begitu diharapkan pemuda Desa Cipacing akan termotivasi dengan kesuksesan dari tiap narasumber dalam mengelola usaha dan memanfaatkan internet dalam mencapai kesuksesannya. Dalam workshop yang bekerja sama dengan perusahaan penyedia internet ini, akan dijelaskan bagaimana pemanfaatan teknologi dan intenet yang baik dalam menunjang keberhasilan sebuah produk di pasaran. Dengan mengaplikasikan suatu sistem informasi yang berbasis teknologi di dalam sebuah usaha dapat memberikan keuntungan bagi pengusaha tersebut antara lain: sebagai salah satu sumber daya organisasi yang menunjang kegiatan operasional, dan manajerial, memberikan informasi yang akurat dan tepat waktu, dan tersaji dalam bentuk yang sesuai, serta menunjang keunggulan kompetitif usaha.

\section{HASIL DAN PEMBAHASAN}

Desa Cipacing memiliki beberapa potensi sumber daya, yaitu sebagai berikut;

1. Lahan untuk pertanian dan cocok tanam. Maraknya pembangunan pemukiman di Desa Cipacing memang mengurangi jumlah lahan untuk pertanian dan cocok tanam, namun Pemerintah Desa Cipacing telah bekerja sama dengan Universitas Padjadjaran khususnya dengan dosen-dosen dari Fakultas Pertanian dan Fakultas Teknologi dan Ilmu Pangan dalam kegiatan pengabdian masyarakat dan pelatihan terhadap warga mengenai pemanfaatan pekarangan sebagai lahan bercocok tanam dan juga berbagai teknologi baru dalam bercocok tanam. 
2. Industri senapan angin, industri rumahan ini dikelola oleh Koperasi Bina Karya (berlokasi di RW 08) dan pembuatannya masih bersifat manual. Pengrajin senapan di Desa Cipacing bisa memproduksi beberapa jenis senapan, yaitu Senapan Angin, Senapan Gas, dan Senapan Per. Senapan buatan pengrajinpengrajin Desa Cipacing ini sendiri sudah dipasarkan hingga ke luar kota dan sampai saat ini masih menjadi ciri khas atau usaha yang paling terkenal di Desa Cipacing

3. Kuliner, sebagai kawasan Sunda, Desa Cipacing juga kaya akan kuliner tradisional seperti nasi tutug oncom, lotek, surabi, dan masih banyak lagi. Namun, kuliner-kuliner warga sangat jarang mampu menembus pasar di pusat desa atau di antara konsumen yang mayoritas adalah masyarakat urban (tidak tetap) yaitu mahasiswa dan karyawan. Hal tersebut dikarenakan semakin banyaknya restoran-restoran atau kafe dengan suasana yang nyaman serta aneka makanan dan minuman sehingga lebih disukai oleh pasar yang merupakan mahasiswa dan karyawan.

Pengembangan potensi kuliner tradisional buatan masyarakat Desa Cipacing dengan memberdayakan peran pemuda/i desa untuk meningkatkan usaha kuliner yang pemasarannya berbasis online atau melalui media sosial. Alasan penulis memilih potensi kuliner untuk dikembangkan adalah sebagai berikut:

1) keprihatinan terhadap ketidakberdayaan masyarakat desa untuk mengembangkan usahanya dalam bidang kuliner akibat kalah saing dari usahausaha kuliner modern yang mulai menjamur di sekitar Jatinangor, khususnya di Desa Cipacing;

2) Masyarakat terutaman perempuan usia produktif merupakan penduduk yang mampu dan fasih dengan teknologi, khususnya dalam bermedia sosial sehingga menjadi penting untuk memaksimalisasi peran perempuan dalam memasarkan kuliner desa melalui media sosial untuk menyokong perekonomian desa, khususnya dalam meningkatkan pemasaran usaha kuliner masyarakat;

3) masyarakat Desa Cipacing yang kaya akan kuliner tradisional khas Sunda merupakan kekayaan budaya yang harus dilestarikan dan dikembangkan, oleh karena itu potensi kuliner harus dikembangkan dengan memasarkannya melalui banyak platform dan media sosial sehingga dapat mencakup banyak konsumen dan meningkatkan penjualan;

4) perkembangan teknologi yang kini mendorong berbagai kegiatan ekonomi untuk mengembangkan usahanya dalam bentuk online atau berbasis media sosial juga menjadi alasan pentingnya untuk memberdayakan masyarakat Desa Cipacing, dengan tujuan mampu menguasai dan memperluas pasar melalui berbagai media, khususnya dalam bidang usaha kuliner tradisional.

Berdasarkan hasil yang telah didapatkan, fokus permasalahan yang kami pilih terletak pada sumber daya manusia terutama sumber daya pemuda usia produktif di RW 01 Desa Cipacing. Sumber daya manusia pemuda RW 01 Desa Cipacing dapat diberdayakan. Solusi yang kami tawarkan terhadap permasalahan kurangnya minat pemuda akan bisnis kerajinan tangan serta kurangnya pengetahuan dan kesadaran pemuda dalam pemanfaatan teknologi internet adalah diadakannya workshop bekelanjutan mengenai bisnis dan pemanfaatan teknologi internet untuk membangkitkan minat dan pengetahuan para pemuda di Desa Cipacing. Dengan begitu diharapkan pemuda Desa Cipacing akan termotivasi dengan kesuksesan dari tiap narasumber dalam mengelola usaha dan memanfaatkan internet dalam mencapai kesuksesannya. Dalam workshop yang bekerja sama dengan perusahaan penyedia internet ini, akan dijelaskan bagaimana pemanfaatan teknologi dan intenet yang baik dalam menunjang keberhasilan sebuah produk di pasaran. Dengan mengaplikasikan suatu sistem informasi yang berbasis teknologi di dalam sebuah usaha dapat memberikan keuntungan bagi pengusaha tersebut antara lain: sebagai salah satu sumber daya organisasi yang menunjang kegiatan operasional, dan manajerial, memberikan informasi yang akurat dan tepat waktu, dan tersaji dalam bentuk yang sesuai, serta menunjang keunggulan kompetitif usaha.

Seperti yang kita ketahui media sosial saat ini sangat berperan penting dalam membranding sebuah produk. Dengan adanya workshop ini diharapkan mampu memaksimalkan branding hasil karya kerajinan tangan dari Desa Cipacing. Sehingga dapat semakin dikenal banyak orang dan semakin besar kesempatan untuk menghasilkan keuntungan yang lebih berlimpah.

Dalam kegiatan workshop tersebut, pemuda RW 01 Desa Cipacing akan dibagi menjadi beberapa kelompok. Tiap kelompok akan dipimpin oleh satu orang mentor yang kredibel dalam dunia bisnis. Semua kelompok akan terus dibina oleh masing-masing mentor dalam beberapa bulan ke depan sampai pemuda mampu menjalankan bisnis online dengan baik. Mentoring ini merupakan program berkelanjutan dari workshop yang sudah dilakukan sebelumnya. Adanya mentoring ini sangatlah penting sebagai upaya peninjauan sejauh mana pemuda RW 01 Desa Cipacing mampu memanfaatkan teknologi internet dan mengembangkan usahanya dengan baik.

Jika dikaitkan dengan teori Konstruksi Sosial. Teori ini menjelaskan pengetahuan individu mengenai kenyataan fakta objektif tentang dunia ditentukan oleh lingkungan sosial dimana pengetahuan itu diperoleh dan disalurkan. Berdasarakan pernyataan dari teori tersebut, potensi yang dimiliki oleh pemuda RW 01 Desa Cipacing berasal dari lingkungan tempat tinggal mereka yang sudah berlangsung secara lama di bidang kesenian, khususunya kerajinan tangan. Kenyataan dan realitas sosial ini pada dasarnya adalah simbol dimana seseorang mempunyai kemampuan untuk menggunakan dan mengaplikasikan simbol tersebut. Teori ini mengkaji hubungan antara pemikiran manusia dengan konteks sosial dimana suatu ide atau pemikiran itu muncul, berkembang, dan disahkan. Oleh karena itu, jika dikaitakan dengan realitas yang ada, kemampuan seni yang dimiliki oleh para pemuda 
RW 01 Desa Cipacing sangat bisa dimanfaatkan dengan sebaik-baiknya.

Pemberdayaan Pemuda RW 01 Desa Cipacing Dalam Memaksimalkan Bisnis Kerajinan Tangan Melalui Pemanfaatan teknologi Internet

Terdapat beberapa potensi yang ditemukan di Desa Cipacing mulai dari RW 01 hingga RW 04. Potensi tersebut berupa kerajinan tangan seperti karimba, suling, celengan, halilintar, panah, ketapel, tik tok, jimbe dan kecrekan, barang rajutan, dan senapan angin. Potensi pertama yaitu kerajinan tangan yang ada di wilayah RW 01 Desa Cipacing. Sebenarnya potensi tersebut bisa dikembangkan oleh pemuda yang berada disana. Karena mereka telah memiliki bekal kemampuan untuk membuat sebuah karya seni. Namun pada nyatanya, saat ini para pemuda memilih bekerja di luar kota atau menjadi buruh pabrik. Alasannya tak lain adalah karena anggapan mereka bahwa kerajinan tangan merupakan usaha yang tidak begitu menjanjikan seperti dahulu dan pekerjaan lain seperti buruh pabrik merupakan pekerjaan yang lebih menjanjikan.

Potensi kedua ada di wilayah RW 02 Desa Cipacing yaitu pembuatan barang rajutan yang dilakukan oleh para ibu rumah tangga. Ibu rumah tangga sebagai sumber daya manusia yang mampu menghasilkan barang rajutan tersebut. Kegiatan merajut awalnya merupakan salah satu program Kuliah Kerja Nyata/KKN mahasiswa dengan menghadirkan seorang pelatih untuk merajut. Kegiatan ini juga dianggap sebagai sebuah kegiatan menarik dan bermanfaat. Selain dapat mengisi kekosongan waktu, dengan merajut juga dapat menambah penghasilan rumah tangga mereka.

Potensi ketiga adalah pembuatan kerajinan senapan angin yang dilakukan oleh banyak kepala keluarga di RW 03 dan RW 04. Pembuatan senapan angin ini sejak dahulu dijadikan pekerjaan pokok oleh mayoritas keluarga di sana. Bahkan kerajinan senapan angin ini sudah terkenal di kota-kota besar di Indonesia. Hal inilah yang membuat pekerjaan ini dijadikan pekerjaan pokok dan masih digeluti sampai sekarang.

\section{SIMPULAN}

Dari ketiga potensi yang ada di Desa Cipacing tersebut, kami memilih satu potensi yang kami rasa dapat dikembangkan secara maksimal dibantu dengan perkembangan teknologi saat ini dan tentunya memiliki nilai profit yang tinggi jika dilaksanakan dengan baik, yaitu potensi yang ada pada pemuda RW 01 Desa Cipacing untuk mengembangkan dan ikut serta dalam bisnis kerajinan tangan dengan memanfaatkan teknologi internet. Solusi yang kami tawarkan adalah dengan mengadakan workshop berkelanjutan mengenai bisnis dan pemanfaatan teknologi internet untuk membangkitkan minat dan pengetahuan para pemuda di RW 01 Desa Cipacing. Dengan begitu diharapkan pemuda RW 01 Desa Cipacing akan termotivasi untuk menggapai kesuksesan saat mengelola usaha kerajinan tangan. Hasil dari kegiatan workshop ini akan berlanjut dengan program mentoring bagi para pemuda RW 01 Desa Cipacing dalam menjalankan bisnisnya.

\section{DAFTAR PUSTAKA}

2017. Kecamatan Jatinangor Dalam Angka. Sumedang : BPS.

Suharto, Edi. 2005. Membangun masyarakat memberdayakan rakyat. Bandung: Refika Aditama.

Imaduddin, Abdul Malik. 2016. Desa Cikeruh. Diakses pada 03 Juli 2018 dari : http://sumedangtandang.com/direktori/detail/desacikeruh.html

Saputro, Thomas. 2015. Metode Pemberdayaan Masyarakat (RRA dan PRA). Diperoleh tanggal 03 Juli 2020 dari : http://www.ilmuternak.com/2015/02/metodepemberdayaan-masyarakat-rra-pra.html

Rinawati, R. (2009). Komunikasi dan Pemberdayaan Masyarakat. Bandung: UNPAD PRESS.

Susanti, Idha. Teknologi Informasi Dalam Menunjang Kesuksesan Bisnis.

http://idha.blogstudent.mb.ipb.ac.id/2011/07/16/teknologi -informasi-dalam-menunjang-kesuksesanbisnis/.(Diakses pada 1 Juni 2020) 